\title{
Colonus in England's Green and Pleasant Lands: William Mason's Caractacus and His Use of Sophocles
}

\section{Cressida Ryan ${ }^{1}$ (1)}

Accepted: 22 September 2020 / Published online: 2 January 2021

(c) The Author(s) 2021

\section{Introduction}

William Mason's 1759 play Caractacus announces itself as 'a dramatic poem on the model of the antient Greek tragedy', but what this means as a process of reception is never made clear. In this article, I explore this modelling process in its 18th-century context. Mason himself writes that he seeks to 'mingle Attic art with Shakespeare's fire. ${ }^{1}$ Caractacus offers a case study investigating how Britain could absorb Greek tragedy as part of a nationalist sublime aesthetic, mingling themes of politics and religion and contributing to the developing aesthetic landscape. ${ }^{2}$ Edith Hall and Fiona Macintosh ascribe the main element of this Attic art to the play's use of a chorus. ${ }^{3}$ I first respond to this claim by extending discussion about the role of the chorus in Caractacus. I also argue that one of the main ways in which the play combines art and fire is in its aesthetic tone, as an example of a new form of sublime literature which takes its inspiration from Longinus via Burke, rather than from Aristotle. It is this lens of the sublime that helps us to understand the play's relationship with both Classical literature and contemporary circumstances. This different form of modelling also incorporates the ways in which Greek tragedy uses theatre to communicate with the public (especially on religious topics) while avoiding censorship. Robert Walpole had introduced theatre censorship in 1737. Political satire was becoming a more common vehicle for commentary on contemporary politics. ${ }^{4}$ Censorship had made overt allegory and satire impossible. Using a Greek tragedy as a model

\footnotetext{
1 Preface to Mason (1796, vi-vii.

2 Note that in Caractacus it is always Britain and not England/Wales/Scotland. This sense of the construction of a nation is discussed further below.

3 Hall and Macintosh (2005).

4 See Brewer (1986) and Miller (1986) on the emergence of political and religious artistic satire. Gulliver's Travels also played an important part in this growth of satire.
}

Cressida Ryan

cressida.ryan@theology.ox.ac.uk

1 Faculty of Theology and Religion, University of Oxford, Radcliffe Observatory Quarter, Woodstock Road, Oxford OX2 6GG, UK 
allowed Mason to appeal to the Classics while continuing to comment on contemporary situations. Fiona Macintosh has already demonstrated clearly the importance of Greek tragedy in this process. ${ }^{5}$ Part of Mason's use of models is to appeal to the way in which Greek tragedy is used to comment on contemporary issues without invoking the censor's red pen. Mason's claim to use the Greek tragedy as a model is in part also an invitation to read Caractacus in the kind of allegorical way that Greek tragedy was being used, and this article seeks to understand some of this process. ${ }^{6}$

\section{More than the Chorus}

Caractacus has received little prior attention. ${ }^{7}$ Hall and Macintosh take it for granted that Caractacus is based on the Oedipus at Colonus (henceforth $O C$ ), but there is a broader modelling of the play on various aspects of other Greek tragedies. A brief plot summary may help introduce readers to the play and suggest points of contact with tragic plots:

Aulus Didius enters a grove on Mona (Anglesey) with some Roman soldiers. He encounters Vellinus and Elidurus, two young local brothers. He explains he is looking for Caractacus, in order to capture him and take him to Rome. Vellinus decides to betray Caractacus; Elidurus is opposed to this. A band of druids, headed by Modred, the chief druid, enter. Caractacus arrives with his daughter, Evelina. They hymn the place, and discuss the rites they are there to perform. After a choral interlude led by the druid Mador, the characters are disturbed by Vellinus and Elidurus. Vellinus explains the threat of the approaching Romans, but seeks to deceive Caractacus that he has a message from Caractacus' lost wife, Cartismandua. After another chorus, Evelina expresses her mistrust of Vellinus. Modred sets an initiation challenge, wherein Elidurus is confined to a cave. Elidurus confesses the treachery to Evelina. Evelina's lost brother, Arviragus, returns, and explains he has seen Romans in the area. Vellinus' plot is therefore uncovered. Elidurus explains the situation, and is forgiven, joining in to support Caractacus. Vellinus defects completely to the Romans. Evelina intercedes on Elidurus' behalf with the druids. Elidurus and Arviragus go off to fight the Romans, reported by the druids. Evelina is anxious about what has happened. Arviragus returns, fatally wounded. Elidurus vows to support them. A bard announces that the grove has been surrounded. Aulus Didius enters and captures Caractacus and Evelina,

\footnotetext{
5 Macintosh (1995).

6 Mason's commitment to satire and allegory can be seen in his extensive correspondence with Horace Walpole. This focusses on literature and politics, the two things Mason wanted information on for the sake of writing satirical literature of his own.

7 Indeed, in Cheney et al. (2012, vol. 3, 1660-790), there are only three references to Mason. Two are brief mentions of The English Garden, the third a reference to Mason's neoclassical aesthetic. Caractacus and its relationship with Greek tragedy is not mentioned.
} 
At a very basic level, the setting in front of a cave recalls Philoctetes; the tension between brothers perhaps evokes Antigone (echoed in the $O C$ ); the use of tokens to convey messages and offer proof of identity suggests an Electra. The $O C$ can be heard in Evelina's role as negotiator, in her ability to argue for Arviragus in a way Antigone fails to do for Polynices. The most obvious resonances, however, come in the combination of place, religious atmosphere, and overall spirit, beyond the tropes of old man, war, and daughter. This is not a play with Greek characters, but one with a Greek soul.

Caractacus is not Mason's first tragedy on the Greek model; in 1752 he published Elfrida. ${ }^{8}$ Composed during his time at Cambridge, and first published in 1759, Caractacus was not performed for a further seventeen years. ${ }^{9}$ Caractacus and Elfrida were both closet dramas, never intended for the stage. ${ }^{10}$ To write closet dramas was hardly unusual; 'doing' tragedies into English was a pastime of the educated Englishman, a common exercise. ${ }^{11}$ What was unusual about Mason's efforts is that they made it to the stage.

Both plays declare themselves to have been written on the Greek tragic model, but the influence of Greek and Latin literature is far broader than tragedy. In Caractacus, Mason drew on a formidable range of sources. He is frequently criticised for being too derivative, yet one biographer accuses him of reading too little. ${ }^{12}$ In the appendix to the 1796 British Museum edition of Caractacus, a range of Greek and Roman sources for the play are cited. These are introduced as an aid to understanding the play in its classical context. ${ }^{13}$ No dramatist is cited in support of the play's prefatory claim to tragic form. The cited sources pertain to the content of the play, and its druidical nature. A more subtle link demonstrating the Sophoclean spirit behind the druidical aspect of the play may, however, be drawn via the Lucanian material. I suggest that it is this inspiration by spirit rather than letter which characterises Caractacus. It is only by understanding this subtle configuration of linguistic and thematic issues alongside the formal ones raised by Hall and Macintosh that we can make sense of the play's success. ${ }^{14}$ In order to demonstrate this, I turn first to consider the chorus in Caractacus, and other more formal elements of Greek tragedy.

\footnotetext{
${ }^{8}$ This may have been conceived of as early as 1749 , and it was not produced until 1772; see Draper (1924, p. 28).

${ }^{9}$ He may have had the idea for Caractacus as early as 1756; see Gaskell (1951, p. 374).

${ }^{10}$ Although Hall and Macintosh (2005, p. 189) describe Caractacus as an impressive stage play; this shows how plays not initially destined for visual representation can in some circumstances transfer successfully to the stage.

${ }^{11}$ See Hall and Macintosh (2005, pp. 61-2).

12 See Draper (1924, p. 64).

13 These sources are Ammianus Marcellinus, Strabo, Caesar, Pliny, Tacitus, Lucan and Dio Chrysostom.

14 This cultural contingency also made Caractacus very much a play of its time, as is true of much of the rest of Mason's work; it was extremely popular on stage, but has been neglected since, sounding stilted and awkward to a modern ear. See Draper (1924, p. 3.)
} 


\section{Neoclassicism Challenged-Elements of Form}

Both Caractacus and Elfrida include lyric odes between scenes, dividing them into episodes in a manner not previously attempted by an English writer. Hall and Macintosh make this change the focus of their work on Caractacus, viewing it as the main sign of Mason's classicism. I first give a summary of their position, before considering how it could be broadened out. For them, the chorus provided the primary criterion for judging the success and quality of the play, as they emphasise the novelty of Mason's conflation of Hellenic and ancient British revivalism. ${ }^{15}$ Mason is supposed to have taken his cue from Handel's reliance on a chorus. ${ }^{16}$ As with Handel, Mason's choruses were criticised as an unusual formal innovation. ${ }^{17}$ Greek choruses are known for commenting on the action, but there were concerns that a moralising chorus might disguise dangerous materials. ${ }^{18}$ One train of contemporary opinion was also that the chorus represented the decline in Athenian freedom, a feature of the time after the theoric fund was established, intended to mask the decreasing political freedom of ancient playwrights. ${ }^{19}$ The theoric fund, however, and theatre's important place in Athenian law, was instead praised in Mason's circle. ${ }^{20}$ This link between the chorus and politics is evident in Richard Hurd's claim that the chorus only speak the truth if they are citizens; aesthetic and political choices are two faces of the same creative process. ${ }^{21} \mathrm{We}$ do not find his comments levelled at Mason in particular, however. Indeed, in Walpole's extensive (42-volume) correspondence, Caractacus is barely mentioned, let alone criticised. ${ }^{22}$ Mason's use of the chorus was unusual, but not unintelligible in its context. Hall and Macintosh have picked this element out as the most important part of Mason's Classicism, but I suggest that there is more to his use of choruses, and his Classicism, that needs closer inspection. I therefore now turn to consider the role of music and choruses in Caractacus as

\footnotetext{
15 Hall and Macintosh (2005, p. 184). They also point out that Milton's 1671 Samson Agonistes was influenced not only by tragedy in general, but by the $O C$ in particular. Caractacus may have been the first reworking of the whole play, but elements are there in earlier literature, including Shakespeare's King Lear. As they argue: an epistle to the play invites formal and thematic comparison with Greek tragedies and the play features an onstage chorus (12); the clergy was usually in favour of choruses but dramatists against, with Mason reconciling them in 'druidical revivalism' (198); the chorus was supposedly an expression of Epicureanism, and thus conflates the Christianity of the clerical author, native paganism and Hellenistic philosophy, a contradictory mix worthy of expanded comment further on (206). I will not engage with tragedy and Aristotelian form in this article, as other elements of Caractacus are more interesting to pursue for translation purposes.

16 Hall and Macintosh (2005, p. 197). Note that Hercules is the first recorded modern production/adaptation of Trachiniae. The first recorded stage production is Samuel Parr's 1776 Stanmore School production, which was backed by David Garrick, in the same year as Caractacus was produced.

17 Hall and Macintosh (2005, p. 208), quoting Stockdale An Inquiry into the Nature and Genuine laws of Poetry (1778: 117, 119).

18 Hall and Macintosh (2005, p. 199).

19 Hall and Macintosh (2005, p. 200).

20 See for example Horace Walpole writing to Mason, 12 May 1778, in Walpole and Lewis (1937, p. 393).

21 Hall and Macintosh (2005, p. 200).

22 Just fourteen letters mention Caractacus.
} 
more than a structural device. In so doing, I move from responding to Hall and Macintosh to beginning to consider how thematic ideas help to explain Mason's form of modelling, in particular, the concept of the sublime.

The musical traditions of Greece and Britain are conflated in Caractacus. There was a contemporary craze for Celtic musical traditions, where Celtic interests were inseparable from that in the music of Ancient Greece. ${ }^{23}$ Elements of this were already evident; from the late 16th Century onwards opera had been evolving as a genre intended in part to recreate Greek tragedy, and opera was a popular genre in the elite circles of 18-century England; from 1750-1760 approximately 25\% of all new dramas on the London stage were operas. ${ }^{24}$ Greek tragedy expressed through music had precedents in opera; music and choral writing were paired in oratorio; ${ }^{25}$ Greek tragedy's integration of a musical and spoken chorus into a spoken dramatic, fictional narrative was not so well accepted, and it is here that Mason innovated in choral terms. Mason's own two tragedies on the Greek model were both performed with music by Thomas Arne; Arne plays a further part in this story, as the composer of the music for Thomson's Rule Britannia (itself part of a tragedy, Alfred), to which I return below. The choruses were more complex than simple music interludes, however. The 1796 edition marks the musical parts of the text with double inverted commas, and the stage directions describe them as symphonies. ${ }^{26}$ Mason has been described as the master of Britain's choruses, represented with a lyre, a symbol of Greece. Choral writing was invoked in praise of Mason's writing, as well as censure. ${ }^{27}$ Here, however, we see the influence of Roman and other Greek sources beyond those acknowledged by Mason in the appendix to the 1796 volume. The second chorus of Bards recalls comments by Diodorus Siculus (5.31). Here bards are differentiated from druids proper, and associated closely with the lyre. In Caractacus, we find both a singing and a speaking chorus, with music made integral to the play. ${ }^{28}$ The singing chorus are the bards, the speaking chorus are the druids. Both are part of the same group of worshippers in the sacred rites, but there is a difference between them. Exploring this ritual context as a place of innovation will demonstrate a new way of examining Mason's Classicism. This new mode of interpretation is the sublime.

Where Horace Walpole does mention Caractacus in writing to Mason, he offers positive encouragement for choruses:

\footnotetext{
23 Hall and Macintosh (2005, pp. 192-3).

${ }^{24}$ Handel's last new opera, Deidamia, was first performed in 1741. His decision to give up opera seems due in part to his disillusionment over the potential for opera seria to provide social comment given the ambiguity of allegory and restraints of censorship.

${ }^{25}$ For an introduction to Greek tragedy and opera, see Brown and Ograjenšek (2013), Ewans (2007) and McDonald (2001).

${ }^{26}$ In the parodos, for example, it reads: 'The Chorus, preceded by Modred, the Chief Druid, descend to a Solemn Symphony'.

27 See Hayley (1782) Epistle I, ii.13-14, quoted in Walpole and Lewis (1937, xxvi).

28 Although the double chorus has links with the history of the Druids.
} 
As you are sublime in choruses, why have you only one in an opera, -in a Greek opera? They are simple and yet give variety; surely a hymeneal chorus is necessary? ${ }^{29}$

Walpole referred to Mason as 'sublime' in his choruses, an aesthetic term which was gaining prominence in the eighteenth century. In examining what Walpole might have meant by this, we begin to see the relevance of the $O C$ as a model for Caractacus.

\section{Caractacus and the Sublime}

If we are to link Caractacus to any specific Greek tragedy, it is, as Hall and Macintosh suggest, the Oedipus at Colonus. At first glance, this link can be made on the basis of the old men under duress with attendant daughters. The setting is also comparable, based in sacred groves in a ritual context. A question remains as to why the $O C$ offers a suitable model; before considering its relationship with the sublime, it is worth noting its position in relation to the Oedipus at Tyrannus. Since the publication of Robortello's edition of Aristotle's Poetics in 1548, the Oedipus Tyrannus (henceforth $O T$ ) had been cited as the perfect Greek tragedy. ${ }^{30}$ In terms of musical receptions alone, opera has been discussed as an attempt to recreate the fusion of genres experienced in Greek tragedy, combining dance, words and music with various forms of staging. ${ }^{31}$ In Caractacus, we see a further phase in this history of the development of western theatrical traditions. The $O T$ had been both a foundational text and a revolutionary one ${ }^{32}$; as such, the $O T$ had been popular in the earlier part of the eighteenth century. Mason himself acknowledged that the OT's time was past in writing about his friend Whitehead's unfinished Oedipus. ${ }^{33}$ As the 'other' Oedipus play, the one not yet performed (Caractacus marks the first staged reception of the $O C$ ), the $O C$ offers a foil to the $O T$. We similarly see Antonio Sacchini use his opera Oedipe à Colone (1785) to enter into the battle between musical styles in the reform of opera which characterised late 18th-century France, positioning himself between Gluck and Piccini as a new kind of composer. ${ }^{34}$ Henry Fuseli, in turn, did two contrasting paintings of the $O C$ (1776-1778 and 1784) which exhibited broadly Aristotelian or Longinian aesthetic characters in turn, as part of his foundation of a movement of neo-Gothic art. ${ }^{35}$ As the century progressed, therefore, we witness a

\footnotetext{
${ }^{29}$ Horace Walpole writing to Mason, 24 January 1778, in Lewis (1937, pp. 345-6). The opera referred to is probably the lost Sappho.

30 See Poetics 1452a, 1453a, 1453b, 1454b, 1455a, 1460a, 1462b. For a thorough history of the reception of the $O T$, see Lauriola (2007).

31 See Burian (1997), Strunk and Treitler (1998) and Tanner (1998).

32 On the $O T$ as a revolutionary eighteenth-century text, see Hall and Macintosh (2005, ch. 8).

33 Mason finished this play for Whitehead, see Draper (1924) and Hall and Macintosh (2005), and Mason's correspondence with Walpole (Lewis (1937, II.405).

34 See Ryan (2010, ch. 5). Note that this opera it itself modelled on Caractacus, and Sacchini's next (and final opera) was an explicit homage to Caractacus called Arvire (Arviragus) et Evelina.

35 See Ryan (2010, ch. 4).
} 
shift away from the standard neoclassical ideal. ${ }^{36}$ This manifested itself in the development of a new aesthetic culture, that of the sublime, and then the neo-Gothic. With this shift, came the opening up of relatively unknown works to greater appreciation. The $O C$ offers a new start for the Oedipus tradition.

The development of the sublime in the eighteenth century is a well-documented story. Pertinent to this article is its development in the work of Edmund Burke. Burke's Philosophical Enquiry was first published in 1757, at just the point Mason was writing Caractacus. I have argued elsewhere how Burke offers a very particular remodelling of Longinus; in reading Burke we are also accessing a Longinian way of viewing literature. ${ }^{37}$ For Burke, the sublime pertained to our human desire for self-preservation and solitude and was linked to the experience of delight. Terror was also related to the desire for self-preservation ${ }^{38}$; the sublime aesthetic which fed into the development of tragedy was in part a move from the fear that related to Aristotelian poetics, to the terror which drew on Longinus. Burke's sublime required the senses to be suspended in astonishment, and he listed a number of features that would achieve this sensory overload. This was not achieved through anything beautiful or measured, but through excess. The result was a disabling astonishment of the soul and fear, as apprehension of pain or death. Greek and Latin expressed this through words such as $\delta \varepsilon \imath$ ós, vereor and $\alpha i \delta \varepsilon \dot{o} \mu \alpha \imath$ which carry this fear and astonishment combined. Despotism and religion both express the combination of fear and awe; Burke's example is druids in the depths of oak woods. This is a dark, confused, uncertain, terrible situation, and therefore sublime. ${ }^{39}$ Similarly, wherever God speaks it is terrible, and therefore awesome, and therefore sublime. ${ }^{40}$ These ideas begin to surface in the new genre of the neo-Gothic model, beginning with Horace Walpole's The Castle of Otranto (1764). ${ }^{41}$ Where Walpole began a new genre, his friend and literary companion, Mason, used Greek tragedy to inform a new kind of sublime drama, and the $O C$ provided a good starting point for this.

The 18th-century Sophoclean translator Robert Potter writes of the $O C$ as a sublime play, with rougher passions that awe and terrify. ${ }^{42}$ The $O C$ is set in the dark grove that is a centre for mysterious religious rites; such a situation begins to offer some reasons why it was a good aesthetic model for writing sublime 18th-century tragedy, in particular, Caractacus. I argue that Lucan, cited as one of Mason's sources but not directly relevant to the plot, now becomes relevant as the bridge between the sublime power of Oedipus in his grove (as referred to by Longinus $\S 15.7)$ and the grove itself in Caractacus. ${ }^{43}$

\footnotetext{
36 See Kalter (2003, p. 998).

37 Ryan (2012).

38 May (1960, p. 530).

39 Burke (1958, p. 59).

40 Burke (1958, p. 69).

41 Braudy (1973, p. 7) also discusses how the novel presages Fuseli's distinction between the details of horror and the (sublime) ineffability of terror; I have already mentioned Fuseli and the $O C$.

42 Potter (1808, p. 66), quoted in Ryan (2010, p. 82). Walpole himself mention's Potter's work to Mason in the same letter (24 January 1778) in which he discusses the chorus (quoted above).

43 Ambühl (2005) provides a discussion of the Theban tragic legend in Lucan, but does not discuss the $O C$. The links between Lucan and Sophocles deserve closer attention beyond the scope of this article and the material presented here is considered only in the context of Caractacus. Sophocles is not mentioned by contemporary or subsequent commentaries on the passage.
} 
Caractacus opens with a description of the setting by Aulus Didius, the Roman invader:

\section{Aulus Didius:}

This is the secret centre of the isle:

Here, Romans, pause, and let the eye of wonder

Gaze on the solemn scene; behold yon oak,

How stern he frowns, and with his broad brown arms

Chills the pale plain beneath him: mark yon altar,

The dark stream brawling round its rugged base,

These cliffs, these yawning caverns, this wide circus,

Skirted with unhewn stone: they awe my soul...

\section{William Mason, Caractacus I.i}

Like Antigone at the start of the $O C$ he is the newcomer to the place, and yet his description is resonant with the same sort of sublime language used to describe the landscape in semiotic terms as we find in the $O C$. His mention of oaks (line 3 ) recalls the Athenian olive in being a tree as central to the British identity as the olive was to the Athenian one; translation here is a form of cultural calquing. The altar (5) recalls that in the centre of the orchestra, and also the fact that both the $O C$ and Caractacus take place in sacred groves; the conflation of religious and theatrical space which marks the $O C$ is maintained in Caractacus, alongside a potentially metatheatrical reading of the text. 'These cliffs, these yawning caverns' recall $\tau$ ò $\nu$

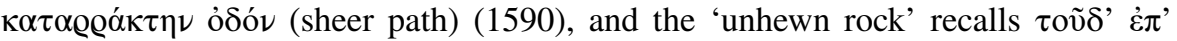

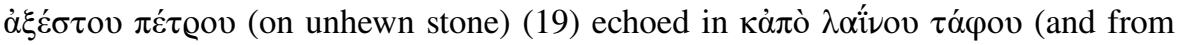
the stony tomb) (1596). The language of majesty and nature, with references to ruggedness, awe, unhewn stone, gloom, the terrific and solemn marks this passage as in keeping with the Burkean sublime, on the way to a Gothic aesthetic.

By claiming to be writing on the model of the ancient Greek tragedy, Mason turns our thoughts towards Greek, and we assume that it is Greek literature to which he must be referring. The weight of Caractacus' Latinity, however, is impossible to ignore, from its Roman setting onwards, and the play provides an excellent example of the potential for fusing the two cultures into a new English model. The geographical and Gothic links in particular become even clearer when we consider this passage alongside the section of Lucan cited in the 1796 British Museum edition appendix (Pharsalia III.399-438). This passage describes a grove, with lines such as

An old unviolated sacred wood,

Whose gloomy boughs, thick interwoven, made

A chill and cheerless everlasting shade:

There nor the rustic gods nor satyrs sport,

There nor the feathered songster builds her nest,

Nor lonely dens conceal the savage beast:

There no tempestuous winds presume to fly;

E'en lightnings glance aloof, and shoot obliquely by. 
No wanton breezes toss the dancing leaves,

But shivering horror in the branches heaves.

Black springs with pitchy streams divide the ground,

And, bubbling, rumble with a sullen sound.

Lucan Pharsalia III.399-438 (extracts) translated by Nicholas Rowe

(1703-18).

The inclusion of this passage in the appendix to Caractacus invites us to consider its relationship with the play. I suggest that Lucan's grove subverts Sophocles'; Lucan shows the negative potential of the place Sophocles eulogises. Rowe's (loose) translation echoes the language of the Gothic sublime, couching Sophoclean ideas in Lucan's verse with a Longinian spirit. The Lucanian grove has been described as in keeping with the tradition of the locus amoenus. ${ }^{44}$ The Colonus ode has also been described in such terms, but only Seneca's influence on Lucan is noted by commentators. ${ }^{45}$ Reading the two next to each other demonstrates how sublime (in Burkean terms) the $O C$ could become. Alongside the 'boughs, thick interwoven', it suggests $O C$ 16-17 'A sacred land, so it seems to me, teeming with laurel, olives, grapevines' or even the Colonus Ode (671-677):

Where the nightingale, a constant guest, trills her clear note in the covert of green glades, dwelling amid the wine-dark ivy and the god's inviolate bowers, rich in berries and fruit, unvisited by sun, unvexed by wind of any storm. ${ }^{46}$

The everlasting shade (402) and lack of winds $(411,413)$ pick up the adjectives

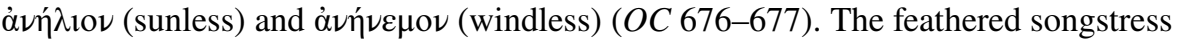
(409) recalls the nightingales so prevalent in the $O C$. The hollow depths (426) suggest both the descent to the underworld implied at $O C$ 1590-1591, and the underground caverns and passages in Caractacus. Explicit references to fear, dread, horror and awe $(405,414,430,432,424,432,436,437)$ give us immediate access to the sublime in Longinian and Burkean terms. 'terrible to sight' does not translate

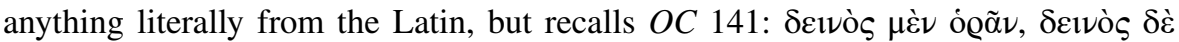

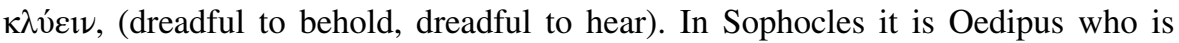
dreadful to see, in Lucan, the demon of the place; these are not precise parallels, but there is a parallel in terms of atmosphere, and a hint at the potential reading of

\footnotetext{
44 Hunink (1992, p. 168).

45 On the Colonus Ode as a locus amoenus, see Bierl (1991, p. 100). This idea merits closer discussion in terms of fifth-century Athenian literature, but such a study is beyond the scope of this article. On Seneca's influence on Lucan's grove, see Hunink (1992, p. 169). He also notes the influence of Lucan on Thebaid 2.496-523 and 4.419-442, demonstrating a continued theme of topographical importance in the Theban legend.

46 Extended translations are from Jebb (1885).
} 
Oedipus' own growth into a daemonic figure. ${ }^{47}$ The awesome terror of Philosophical Enquiry II.i is summarised neatly at Pharsalia III.420 'Strikes the astonished gazer's soul with dread'. References to lightning $(412,429)$ confirm this link.

This aesthetic link between Sophocles, Lucan and Mason through the sublime is consistent with contemporary writings about the sublime. In his notes on Longinus, William Smith had mentioned Caesar in Pharsalia as an example of the vividness which Longinus attributes to Sophocles in the $O C .^{48}$ Furthermore, Geoffrey of Monmouth had used Lucan's description of Caesar fleeing with his back to the Britons in conjunction with his promotion of Caractacus, leading to an established tradition of reading Caractacus with both Lucan and British nationalism in mind. ${ }^{49}$ Eighteenth-century scholars were reading both Sophocles and Lucan in the light of Longinus, and to find echoes of both in Mason demonstrates his strategy of literary conflation in action.

The references to Aulus Didius also require an awareness of Tacitus which returns us to Mason's credited Roman sources. References to works such as Tacitus Annals 14.29-30 and the Agricola suggest a certain level of historical accuracy to the play, much as the declaration at the start does some affiliation with Greek tragedy. This is not, however, a simple link of direct textual influence. Tacitus was extremely wellknown in the eighteenth century and the conflation of the two stories (Aulus Didius and Suetonius Paulinus) would not have gone unnoticed among scholars and pedants. Aulus Didius was not even in the country for the invasion of Mona, let alone the leader of an attack against Caractacus. He assisted Cartimandua, rather than imprisoning her (Tacitus Annals XII.40). The historical detail does not work, nor was it necessarily supposed to work. ${ }^{50}$ Again, Mason is demonstrating what it means to write creatively, engaging with his classical models, but refashioning them to represent England as a new Rome with a Grecian heritage and Celtic background. ${ }^{51}$

Mason's ancient tragic model, therefore, may be partly the formal elements of the Greek tragic chorus. I would argue, however, that it is also, indeed primarily, an aesthetic model. The concept of the sublime, drawing on elements from Greek tragedy and remodelling them in the light of intervening Roman literature and history, becomes a truly new model of writing, a more subtle form of cross-cultural influence, than has previously been acknowledged. It remains to consider why the story and setting of Caractacus in particular were the ones through which to develop such a model.

\footnotetext{
47 See Ryan (2010, pp. 8-9) for a summary of the discussion over Oedipus' daemonic status, and Easterling (2006) (against a daemonic transformation).

48 Longinus (1740, p. 2). An 1800 edition of Dryden with commentary also describes the Pharsalia in precisely such Longinian terms.

49 See Curran (2002, pp. 149ff.).

50 The acknowledged sources are again not, however, the only ones which seem relevant. Aulus Didius' references to their barbarous rites are suggestive of the Druids' notorious human sacrifices. Caesar, Pliny, Dionysius of Halicarnassus and Cassius Dio all mention examples of potential human sacrifice, but only Caesar and Pliny are mentioned by Mason. Dionysius of Halicarnassus had been published in translation in 1758, but Cassius Dio not since 1704, although he is mentioned in Biographia Classica in 1750. This kind of Roman historiography was flourishing in the mid-Eighteenth century and Mason's retelling of it in dramatic form makes sense.

51 For a detailed discussion of the classical sources and eighteenth-century depiction of druids, see Piggott (1974).
} 


\section{Caractacus' Celtic Context}

I have suggested that Caractacus develops elements of the Longinian-Burkean sublime read in Sophocles, through the filter of Rome. I now turn to consider the importance of the conflation of Greek and Celtic culture. It was fashionable in the eighteenth century to identify British/Celtic history with that of Greece. ${ }^{52}$ For Thomas Gray in particular, Greece gave a feminine counterbalance to a masculine Germanic one, and allowed for a rebalanced expression of national identity. ${ }^{53}$ This Hellenising tendency had a long precedent in British literature, where Caractacus had been used as a British hero withstanding the Romans, both before and after the discovery of Tacitus. As the first real contact between Rome and Britain, Caractacus became an easy target for use in anti-Romanism. ${ }^{54}$ In the character of Caractacus, we may discern a conflation of several cultures. Caractacus is an old man who used to be a great king with a famous name and needs to find a place for himself in contemporary society. Caractacus is also modelled on Oedipus, in terms of the father-daughter relationship. In this play, however, it is Evelina who leans on Caractacus, and the motif of mother-slaying is turned on its head:

Caractacus: ...Ah, Evelina!

Hang not thus weeping on the feeble arm

That could not save thy mother.

William Mason, Caractacus I.v

There are also Christian sentiments in the play, which correspond with the potential interpretation of Oedipus within a Christian framework. ${ }^{55}$ Oedipus may be read as the man who became god, who died so that he might protect his people, who holds the power to curse and forgive. Similar ideas are suggested about King Arthur. $\mathrm{He}$ is said not to have died, but to have retired to Avalon, from where he will return should Britain ever need his protection. This is reminiscent of the situation at the end of the $O C$, where Oedipus disappears to an unknown end, ready to protect the land where he has 'died'. ${ }^{56}$ The Arthurian story also has earlier Welsh precedents: in the Mabinogion, when Bendigeid Vran dies (shot in the foot by a poisoned dart), he commands that his head be cut off and left to protect the land outside which it is buried. The Mabinogion may have been little known in England until its translation by Lady Charlotte Guest in 1849 , but that does not mean that it did not influence

\footnotetext{
52 See Hall and Macintosh (2005, p. 186).

53 See Kalter (2003, p. 1001).

54 See Curran (2002) on the use of Caractacus from Geoffrey of Monmouth onwards. Kalter (2003, p. 1002) also notes how absence of historical knowledge gave the poet licence to create, so blank British history is a good thing for Mason.

55 For a thorough discussion of this, see Ryan (2010).

56 For the most comprehensive version of the Arthur legend, see Mallory's translation in Arthur and Southey (1817).
} 
hundreds of years of folk tales, providing a rich pool for Mason to use. ${ }^{57}$ Caractacus draws as much on native myth and legend as it does on Greek tragedy, reminding England of its roots and identifying those roots with Ancient Greece.

This identification continued in terms of place as well as character. Inigo Jones thought that Stonehenge was a Roman monument based on Vitruvian principles. In Caractacus itself, Stonehenge is an astronomical centre. Yet, described as 'choir gaur', it was also given the false etymology 'chorus gigantum/magnum' and thought of as a theatre. ${ }^{58}$ Similarly, the round floor at Trevwry (Anglesey, Tref Alaw) was interpreted as a theatre. Circular structures, therefore, could be interpreted as theatres; they were also associated increasingly with the Greeks rather than the Romans. ${ }^{59}$ There was thus a conflation of Greek and British culture, and of religious and theatrical space, and Caractacus reflects both of these.

In so doing, Caractacus is in keeping with the $O C$ where space and place are key themes, and the integration of locality and religion is vitally important to any interpretation of the play. Mason manipulates the Sophoclean strategies to suit his own ends. In order to make sense of this manipulation in its eighteenth-century context, I now turn to Mason's contemporaries, including the playwright James Thomson and the text of Rule Britannia. Thomson aligned himself in particular with John Dennis, a major contributor to the development of the sublime aesthetic in England, particularly with regard to landscape. ${ }^{60} \mathrm{He}$ drew on Lockean physiology and Shaftesburian moral philosophy, whose precepts we find echoed in Edmund Burke, again with relevance for our understanding of the $O C$. The ideas of ascension, magnificence, pleasure and astonishment ascribed to Thomson all recall contemporary Longinianinspired language.

Thomson's particular familiarity with Greek tragedy was noted at the time, and his combination of Greek tragedy and English nationalistic writing began early in his career. In August 1726, he wrote to his friend Mallet about his latest work that:

They contain a Panegyric on Brittania, which may perhaps contribute to make my poem popular. The English People are not a little vain of Themselves, and their Country. Brittania too includes our native country, Scotland. ${ }^{61}$

This became Brittania, a blank verse poem of just over 300 lines published in Folio, 21 January 1729. Then, on 6 April 1738, his play Agamemnon opened at Drury

\footnotetext{
57 Mason's engagement with such Western literature is perhaps demonstrated by his translation of Knytilnga Saga, the song of Harold the Valiant. He did not read the Norse in which it was written, but translated Mallet's French translation of Bartholinus' Latin translation (see Draper (1924, p. 61). Mason was clearly no stranger to borrowing literature and taking it through multiple translations and the attendant cultural filters. Note that Mallet was James Thomson's best friend in London, on whom more below.

58 Hall and Macintosh (2005, p. 205). This idea is discussed by Horace Walpole in his letter to Conway, 11 November 1787, where he writes: 'Inigo Jones, or Charlton, or somebody, I forget who, called Stonehenge chorea gigantum'.

59 Hall and Macintosh (2005, p. 204).

${ }^{60}$ See Sambrook (1991, p. 44).

61 Sambrook (1991, p. 44).
} 
Lane, where it played for just nine nights, without subsequent revival. ${ }^{62}$ His overt engagement with Greek tragedy failed to impress, but the genre made an impact on him and its influence remains discernible in his later work. Another of his plays, Edward and Eleanora, was the second play banned by the new theatre censorship (in 1740). ${ }^{63}$ Thomson used the Greek model to express views about the unstable political situation in England, and he continued in this vein. In 1740, Thomson and Mallet co-wrote Alfred, a Masque, which was first performed on 1 August 1740 by command of Frederick, Prince of Wales. ${ }^{64}$ This masque includes the chorus now known as Rule Britannia. ${ }^{65}$ The music, like that for Mason's plays, was composed by Thomas Arne. There are significant thematic points of contact between the $O C$, Rule Britannia, and Caractacus. Turning to examine these demonstrates further how Caractacus is part of an emerging literary style, even if it does something different with this. I start with Rule Britannia and the Colonus Ode.

From the very outset of Rule Britannia, there is an emphasis on Britain as divinely protected: 'at Heaven's command' (1) and 'guardian angels sang this strain' (6). Lines 18-19 ('As the loud blast, the blast that tears the skies') invokes the power of the thunderbolt, an instrument of the Old Testament God, but also of Zeus. The Muses, invoked in the last stanza, suggest the fruitfulness of British literature, also implicitly providing their inspiration for this poem itself, as Dionysus was invoked in the Colonus Ode. Britain is symbolised by its mighty tree, the oak (20), as Athens was by its olive. Britain as 'The dread and envy of them all' (14) recalls Athens' olive as a $\varphi$ ó $\beta \eta \mu \alpha$ (source of fear) (OC 699), interpreted by Jebb as a reference to Androtion's story that the Peloponnesian invaders spared the Athenian olives when they attacked. ${ }^{66}$ The Colonus Ode may also celebrate a defeat of the Thebans at Colonus in $411 \mathrm{BC} .{ }^{67}$ Similarly here, Britain is protected against invading tyrants. 'This was the charter, the charter of the land' (3-4) reminds the British of its legal foundation as a free people; such a reference to foundation myths ties in with the focus on Athene and Poseidon in the Colonus Ode.

A relationship can thus be drawn between the use of landscape in the $O C$ and Rule Britannia; whether it is a direct relationship or not, both had an effect on Mason. Mason's use of Sophocles is not in doubt, even if the extent of this use is debateable; his relationship with Thomson requires closer attention. Thomson was connected with the type of artistic elite within whose work Mason's is to be found, including the Walpole family, and the key theatre manager, author and patron of the arts, Aaron Hill. As a satirical writer, Mason was interested in any politics of

\footnotetext{
62 Sambrook (1991, p. 178).

63 It was based on Alcestis, further demonstrating Thomson's engagement with Greek tragedy. It was not performed until March 1775, at the Theatre Royal, which only shortly precedes the production of Caractacus. See Hall and Macintosh (2005, pp. 120-1). Henry Brooke's Gustavus Visa was the first play banned under the 1737 Licensing Act, see Sambrook (1991, p. 191).

64 This places Thomson firmly in the Prince's camp, in opposition to the government. Alfred is also linked to Elfred and thus to Elfrida. Note that this did not mean Frederick was excommunicated, as he had joined the Anglican church, see Lees (2017).

65 It is assumed that Thomson wrote it, but this has not been proven; see Sambrook (1991, pp. 200-1).

66 Jebb (1885, ad loc).

${ }^{67}$ For a summary of the historical references, see Kelly (2009, ch. 1).
} 
literature which he could lampoon, and also with literature that shared his satirical aims. Given Thomson's battle with the censors, his work might well have aroused Mason's interest. They shared a composer in Thomas Arne, who had also composed an Oedipus, King of Thebes, demonstrating his own fondness for Greek tragedy. ${ }^{68}$ There is some biographical reason, then, for crediting Mason with an awareness of Thomson's work. It remains to consider whether there is any textual relationship between the $O C$, Rule Britannia and Caractacus.

I return to Caractacus:

Caractacus: Hail, hallow'd oaks!

Hail, British born! who, last of British race,

Hold you primaeval rights by nature's charter;

Not at the nod of Caesar.

still proudly spread

Your leafy banners 'gainst the tyrannous north,

Who, Roman like, assails you.

William Mason, Caractacus, I.v

As in Rule Britannia, this description is expressed as resistance to tyrannous invaders, with support from the founding charter. Here, the invaders are named Romans. In the next act, Caractacus himself extols Britain's virtue in terms of its divine foundation and protection:

Caractacus: my soul confides

In that all-healing and all-forming Power,

Who, on the radiant day when Time was born

Cast his broad eye upon the wild of ocean

And calm'd it with a glance: then, plunging deep

His mighty arm, pluck'd from its dark domain

This throne of Freedom, lifted it to light,

Girt it with silver cliffs, and call'd it Britain:

He did, and will preserve it.

William Mason, Caractacus II.vi

Whereas in Rule Britannia, Britain rises from the sea by itself, at heaven's command, in Caractacus 'His [God's] mighty arm, pluck'd [it] from its dark domain' (6). Britain is described as 'This throne of Freedom' (7), again couching the description of the land in political terms, perhaps referring to Britain's unusual constitutional monarchy, as opposed to the tyranny it resists. As in Rule Britannia, there is a sense of divine security in 'He did, and will preserve it' (9). At the same time, the tone and phrasing of the speech recalls Shakespeare's Gaunt ("This royal throne of kings, this scepter'd isle..." King Richard II, II.i).

\footnotetext{
68 A new musical version of Dryden-Lee's play, this was first performed at Drury Lane on 19 November 1740, revived in 1744, 1755 and 1775. 1740 is the approximate year of Rule Britannia's composition, 1755 is roughly when Mason was writing his own tragedies, and 1775 falls between the first performances of Elfrida and Caractacus. See Hall and Macintosh (2005, p. 28).
} 
The natural defences, blessed state and Christian protection are all relevant to the Caractacus passages. Mason weaves Latin, Greek and English sentiments and phrases, establishing himself as a new poet for his modern society; he does indeed offer us Attic art mingled with Shakespeare's fire. ${ }^{69}$ These natural defences are in part the hills (or cliffs), which are another point of contact between Caractacus and the $O C$. The precise topography of Colonus is unclear, but Jebb demonstrates that the presence of the hill of Demeter Euchlous mentioned at $O C$ 1600-1601 is important, even if it remains unidentifiable. ${ }^{70}$ In Caractacus, Snowdon is mentioned as a landscape marker, for example:

Chorus: $\quad$ Mona on Snowdon calls...

William Mason, Caractacus I.iv $^{71}$

From the top of Snowdon, it is possible to see Wales, Scotland and England. Not only is it an iconic marker for North Wales, a simple way of letting the audience imagine the setting, but given its access to all three countries, it could be read as a symbol of their unity. Mona is liminal, yet given a central place in the battle for Britain's freedom. Colonus is in a similar situation, on the boundaries of Athens, yet made central to this place. As the site where the Athenians defeated the Thebans in the Peloponnesian War, it also became symbolic of Athenian strength and resistance. The Ossian phenomenon of the 1760s had increased British readers' sensitivity to such Celtic-themed literature, with or without classical resonances. ${ }^{72}$ Wales as a marker of British nationalism made sense in this context. This development meant that on the basis of its Celtic pretensions, Caractacus could become a success on stage in 1776 where it had remained a printed oddity in $1759 .{ }^{73}$ These Celtic echoes are tied as much to religion as they are to place, and I now turn to religion as the second major strand needed to understand Caractacus as a sublime play in its CeltoGreco-Romano context.

\footnotetext{
${ }^{69}$ A similar allegorical reading of landscape is also evident in Mason's other work, most notably his magnum opus, The English Garden, a four-book poem on horticultural themes. For details, see Ryan (2010, pp. 182-3).

${ }^{70}$ Jebb (1885, p. xxxii), and loc cit. See Easterling (2006, p. 143) on the unusual epithet Euchloos for Demeter, which links the place to Eleusis and the Eleusinian mysteries, and the hill is less a topographical reality than a further example of the construction of the dramatic space in religious terms.

71 This appeal to the mountains is also reminiscent of the beacon speech at Agamemnon: 281-316.

72 See Kalter (2003, p. 1009) on how the Ossian phenomenon demonstrated that aesthetic and historical pleasures two different things, with different interpretations and evaluations.

${ }^{73}$ Hall and Macintosh (2005, pp. 193-4) put it as strongly as to say that without the Ossian phenomenon, Caractacus would not have been staged.
} 


\section{The Role of Awesome Wonder}

The Burkean sublime is imbued with a profoundly religious tenor. The overwhelming of our senses becomes a mystical experience. ${ }^{74}$ The landscape provides one important strand of understanding Caractacus as a refashioning of the $O C$ in more overtly sublime terms; a more thorough understanding of the role of religion in Caractacus provides another. Eighteenth-century England witnessed an enormous increase in different branches of Christianity, from denominations such as Methodism which became a part of the Protestant mainstream, to less commonly known groups such as the Swedenborgians and Zwinglians. ${ }^{75}$ Mason had been advised to cease literary work on taking up holy orders. ${ }^{76}$ Contemporary Anglican attitudes were not positive towards performative religion. The Methodists' lack of structured ritual and reputation for excess made them very much figures of fun. At the other extreme lay the Roman Catholics, whose practices were highly performative, and far more elaborate than those of their Church of England counterparts. This play is in part a call for religion to come off the stage; awareness that rituals are appropriate, but only in their proper place, may be one additional message we can take from it. The relationship between this religious instability and both poetic and political productions is important in understanding the increasing prominence of the $O C$.

There is also a link between religious and political affiliations, and the Roman Catholic Church's position. Frederick, Prince of Wales, was the first member of the Royal Family to become a Freemason. James Thomson was a Freemason in the Richmond Lodge, sponsored by the Prince of Wales. In 1738, Pope Clement XII excommunicated all Freemasons. ${ }^{77}$ Mason himself was a Freemason. Hostility between the Freemasons and the Catholics was endemic. This hostility extended throughout society at large, and may provide one way of reading the conflict in Caractacus. In the 1750s, when Mason first wrote the play, the Jacobite rebellion of 1745 would have been relatively fresh in people's memory. Occurring when Mason was just twenty, as an unexpected return to past factionalism, it made a significant impact on the Cambridge set of which he was a part. Anti-Catholic prejudice has a long history, but it received new vigour with such eighteeth-century developments. As Mason then became an Anglican minister, more formal anti-Catholic sentiments

\footnotetext{
${ }^{74}$ For a thorough overview of theories of the sublime see Costelloe (2012), with special reference to religious aspects in ch. 12, Chignell and Halteman (2012).

75 The Wesleian engagement with Sophocles is discussed at Ryan (2010, p. 149), and see Hall and Macintosh (2005, p. 121) on John Wesley's admiration of Thomson's Alfred. William Blake was at one point a Swedenborgian; Henry Fuseli was a Zwinglian priest. The form of Christianity with which these people were involved will colour the way that they read Greek tragedy, and different elements of the tradition will resonate more with each branch. A close examination of Blake's religious affiliations and their effect on his reading of Greek literature would be particularly interesting, given his idiosyncratic affiliations to bizarre groups and his own visionary nature, but this is beyond the scope of this article.

${ }^{76}$ See Nicholas Literary Anecdotes ii.239: 'Although Mason had apparently acquiesced in Warburton's advice to abandon poetry, agreeing "the decency, reputation, and religion, all required this sacrifice of him; and that, if he went into orders he intended to give it up;" his political and literary tastes were too strong for his resolution, and he continued to be an author to the end of his life'. This is reported in St John's Admissions Appendix (1715-1767, pp. 530-1).

77 See Sambrook (1991, p. 168).
} 
would have seemed natural, given the general vilification of Catholics, particularly in the satirical press. By 1776 when Caractacus was performed, the government was trying to make concessions to the Catholics, preparing the Catholic Relief Act of 1778-1780. This Act failed to increase harmony in Britain; instead, Lord George Gordon led riots in London against these reforms after a petition signed by 60,000 people was presented to Parliament on 2 June $1780,{ }^{78}$ and the Scots caused such an uproar that the Act was allowed not to hold in Scotland. ${ }^{79}$ Satirical prints moved towards being explicitly anti-Catholic from around 1746, particularly in $1778-1780 .{ }^{80}$ The production of the play thus came on the approach to the next crisis point for 18th-century Catholicism in England. Its delay in production may reflect in part the wait for an appropriate religious climate as much as an appropriate aesthetic one.

Mason's own clerical life was closely connected with his political and literary life, and this is clearly evident in his work. ${ }^{81} \mathrm{He}$ fell between the enthusiasm of the Methodists and the agnosticism of the Deists, associating poetry with Deist Sentimentalism. ${ }^{82} \mathrm{He}$ viewed Methodism as too close to superstition or to the zeal of the Papists, however, and so never aligned himself too closely with it. A fundamentally charitable man, he took a conservative view on matters of doctrine. His dislike of universal salvation as unscriptural was made clearly evident in one of his published sermons, contemporary with the performance of Caractacus. ${ }^{83}$ This sermon encourages us to be 'religious politicians', bringing our religious convictions to bear on our political attitudes. Believing in the necessity of faith and acts for salvation offers us a way of reading Caractacus whereby character in itself is not enough to condemn or save a man; his actions prompted by that character matter just as much. Elidurus' countenance proves his character as far as Evelina is concerned, but he then begs for the chance to prove himself by deeds, compounding the reasons for accepting him:

Elidurus: Give me a sword and twenty honest Britons,

And I will quell those Romans...

$\ldots$

\section{Gracious Gods!}

Then there are hopes indeed. O call them instant

This Prince will lead them on: I'll follow him,

Tho' in my Chains, and some way dash them round

\footnotetext{
${ }^{78}$ For a comprehensive account of these, see Walpole writing to Mason on Sunday 4 June 1780, Friday 9 June 1780 and Thursday 29 June 1780, Lewis (1937). Note that Edmund Burke was an unnamed advisor on the Act, further linking concepts of the sublime with the contemporary religious and political situation.

79 See Miller (1986, pp. 38-9). The Act was kept; indeed it was supplemented in 1791 by a further Catholic Relief Act, which exempted Catholics from the oath of allegiance, and there was no coordinated opposition or hostility towards this, see Miller (1986, p. 40).

80 Miller (1986, p. 38).

81 Pace Draper (1924), who claims that Mason's literature did not betray his clerical background.

82 Draper (1924, pp. 129, 131).

83 See Mason (1775).
} 
To harm the haughty foe.

William Mason, Caractacus, V.iii

Arviragus is first introduced in absentia as someone whose poor character is demonstrated by his wretched deeds, and who then redeems himself by the way he acts, and explains his acts, both on and off stage. This agreement of character and actions for man's worth is clearly reflected in the way youths are dealt with in the play. The links with salvation are provided by the ending, which looks towards Evelina's future; as he dies, Arviragus makes Elidurus promise to care for Evelina in their enslavement. He asks Elidurus to take on a fraternal role, undercutting the potential romantic link which underlies the text.

For Mason, Christianity was also fundamentally important in establishing a moral framework for life. In 1776, he wrote that faith, hope and love are the marks of a

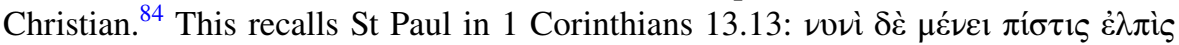

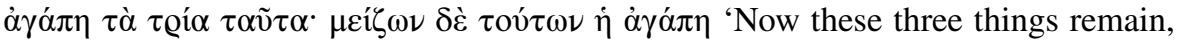
faith, hope, and love; and the greatest of these is love'. It was possible for the eighteenth century to read the $O C$ with a similar message, taking Oedipus' parting words to his daughters (as relayed by the messenger) as inspiration:

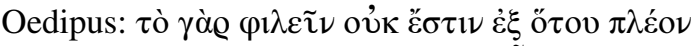

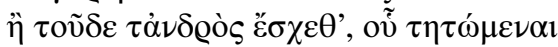 $\tau$ ò $\lambda$ oı \\ For you have had more love from me than from \\ Any other man, which you must now live the rest \\ Of your life without.}

Sophocles OC 1617-1619

$\tau$ ò $\varphi \imath \lambda \varepsilon \tilde{\imath} \nu$ is translated simply as 'love' by George Adams, Thomas Francklin and Robert Potter, as well as later by Jebb. ${ }^{85}$ This is the only place where all three 18 thcentury translations use the word; other examples of the verb are translated in a variety of ways. This idea of the girls being somehow blessed because of the familial love they have received is of great importance, even though it is precisely the disruption of this familial system around which their tragedy revolves. For Mason, familial care was vitally important, and he was a key player in the foundation of the York Asylum (an orphanage). ${ }^{86}$ This expression of familial devotion may well have rung true in his ears. Again, Arviragus' final act of ensuring a protector for Evelina is in keeping with such a model, which already includes a caring (but not incestuous) relationship between Evelina and Caractacus.

In a more overtly religious sense, when the chorus first enter in Caractacus, the play almost carries out a druidical mystery rite before our very eyes, but is interrupted by the interlopers. The audience are teased with the idea of seeing something

\footnotetext{
${ }^{84}$ Mason (1760, p. 7).

85 These translations are discussed in Ryan (2010, ch. 2).

86 See Mason (1788).
} 
they should not. Religion on stage remains taboo, the closest thing being Elidurus' purification rituals. ${ }^{87}$

There are, however, more positive engagements with religion in the play. Elidurus and Vellinus are set up as having largely opposite attitudes towards religion. For Elidurus, local religion, the land and the rites, are of vital importance:

Elidurus: Mercy defend us! See, the awful Druids

Are issuing from their caves: hear'st thou yon signal?

Lo, on the instant all the mountain whitens

With slow-descending bards. Retire, retire;

This is the hour of sacrifice: to stay

Is death.

William Mason, Caractacus, I.iii

Vellinus seems unconcerned by the potential for sacrilege. This conflicting view is also present later, when the druids apprehend them. Vellinus seeks mercy for himself on the grounds of shared nationality, while Elidurus seeks to escape a curse, the symbol of religious hatred, as uttered against Polynices in the $O C$, since he recognises the sacrilegious nature of their intrusion:

Vellinus: O spare, ye sage and venerable Druids!

Your countrymen and sons

Elidurus: spare the curse,

oh spare our youth.

\section{William Mason, Caractacus II.ii}

The 'good' brother is the one who takes religion seriously and wants to display some kind of piety, aware of his youth as a cause of his impious behaviour. This link between religion and age continues throughout the play, albeit at the other extreme. Modred seeks to initiate Caractacus into the company of druids, as the appropriate thing to do with an old man too infirm to govern (at i.iv). Caractacus, as king, continues to order the druids around and is reminded that they, as servants of the gods, need not obey him. This may echo the Catholic situation, where loyalty to Rome might be seen to override loyalty to Britain, especially given the clear line that Pope Clement XII had taken over Freemasons. The druids may be the priests of the local religion, but they can still show traits of where religion and politics are not bound up.

The question of what Caractacus should do, given his age, continues to be important throughout the play:

Caractacus: In this, and all,

Your holy will be done. Yet, surely, Druid,

The fresh and active vigour of these youths

\footnotetext{
87 Note that we also experience such rituals in the $O C$ : 460-509. These rituals, however, are only described (by the stranger to Oedipus) rather than enacted.
} 
Might better suit with this important charge.

Not that my heart shrinks at the glorious task,

But will with ready zeal pour forth its blood

Upon the sacred roots, my firmest courage

Might fail to save. Yet, Fathers, I am old;

And if I fell the foremost in the onset,

Should leave a son behind, might still defend you.

William Mason, Caractacus Iv.iv

Caractacus tries to maintain his authority over the druids immediately after deferring to Modred. The phrase 'Your holy will be done' was excised from the performance edition of the play, perhaps in part due to its Christian overtones, echoing the fiat voluntas tua of the Lord's prayer. Removing it lessens the Christian tone, as well as the deferral to Modred and religious authority in general.

Religious life as an alternative to political power, and the tension between political and religious authority continue to be important themes throughout the play. Caractacus tries to assert his authority over the druids by telling Modred when to begin the initiation rites, failing to realise that the point of these rites is to remove him from power and subordinate him to a greater authority:

Caractacus: Bear with me, Druid,

I've done; begin the rites.

Modred: O would to heav'n

A frame of mind, more fitted to these rites

Possesst thee Prince!

Caractacus I.v (1796) 26.

In the next act, Caractacus comments on the rites and their transformative power:

Caractacus: I feel as should the man

Who, scorning what he was, who, what he is,

Lamenting, rests all future hopes of peace

On what thy rites shall make him.

Caractacus II.i (1796) 31.

This lack of power on Caractacus' part again tallies with idea that, as an ageing king, he is past his time for ruling and should now defer to others and become what is appropriate for him, not taking the role of Oedipus in influencing the tragedy. He expects to undergo some form of transformative initiation and to emerge 'reborn'. This idea of rebirth and rejuvenation reflects the mystery cult underlying the $O C$. Here, however, Oedipus' rejuvenation, which takes place throughout the play, is not the result of others initiating him, but of him growing into a powerful daimon. In 1759 , when the play was written, George II was seventy-six, and a play about an 
ageing king learning where his place lies within a state at war was thoroughly pertinent. By the time that the play was produced, however, George III was on the throne and such a theme was no longer so meaningful. ${ }^{88}$ The play continued to resonate with the audience not because of its overt and particular political references, but because of its representation of the overlap between religion and politics through an aesthetic lens of the sublime.

Caractacus also differs further from the $O C$ in its presentation of the enemy in religious terms. In the $O C$, Theseus accuses Creon of abusing the gods and betraying his homeland in his conduct against Oedipus and his daughters (919-923). In Caractacus the accusations come from the invader, when Aulus Didius twice comments on the rites he has intruded upon. On the one hand, Aulus Didius claims that it is not the Roman way to trample on native religions, but to respect them wherever possible, but at the same time, he both tramples and evangelises:

Aulus Didius: Ye bloody priests,

Behold we burst on your infernal rites,

And bid you pause.

William Mason, Caractacus, V.vii

Aulus Didius thinks he has invaded not just the druids' sacred ground, but also the rites themselves. His next words suggest that he views his invasion of Britain as at least partly altruistic and missionary, disapproving of these rites:

Aulus Didius: 'The Romans fight

Not to enslave, but to humanize the world.'

William Mason, Caractacus V.vii

Hall and Macintosh read Aulus Didius' reluctance to desecrate the grove as a sign that the Romans 'gave licence to all faiths' ${ }^{89}$ Given the multi-denominational situation in Britain, such an interpretation may be possible, but it is unclear which denomination Aulus Didius might be representing. As the invading Roman, Roman Catholicism would seem the most obvious analogue. Yet the Romans are not portrayed as wholly villainous, in contrast to contemporary feeling about Catholics. The desire to humanise the world would be read as both positive (spreading technology, culture and religion to improve people's lives) and negative (imposing a dominant culture assuming that the pre-existing way of life is meaningless). No simple reading of the allegory in religious terms is possible. The polysemic nature of the play is an inevitable consequence of the number of traditions Mason was trying to fuse, and his own deep learning.

\footnotetext{
${ }^{88}$ Note that he did not start to display any symptoms of madness until the 1780 s, so after the production of Caractacus. This means that links between King Lear, Oedipus and Caractacus cannot at this point be drawn.

${ }^{89}$ Hall and Macintosh (2005, p. 189).
} 


\section{Conclusion}

Hall and Macintosh conclude their chapter on Caractacus by saying 'Mason's Caractacus remains confusing, ${ }^{90}$ It certainly remains difficult to decipher, but this article has aimed to suggest some further ways of reading it and gaining access to a work which made sense in its own context but which now seems very remote. Caractacus announces its debt to Greek tragedy. I have argued for viewing this indebtedness as a form of aesthetic attitude and cultural appropriation. Caractacus remodels themes and symbols from Greek tragedy through the lens of Roman literature, while at the same time aligning Greek and Celtic themes in order to position British writing as antithetical to Rome. It draws on the elements of Greek tragedy which informed Longinus' concept of the sublime to create a new kind of sublime British drama. With the motif of the oak we see a translation of symbolic resonance which I have called cultural calquing. The character of Caractacus and the place of Anglesey translate the use of margins to turn boundaries into a centre, making liminality a positive feature in British self-definition. The very structure of the Greek tragedy, with its choruses and acts, is brought into a new context, especially in the light of Shakespearean dramatic structure. The expression of a sublime aesthetic finds itself updated for a new context. Using the $O C$ as a source text in terms of ideology and approach to poetry provided a way of engaging with contemporary aesthetics and the general political and religious atmosphere associated with developments in this field; a new form of tragedy was born, reconceptualising the concept of the tragic against the aggressive politicisation of the OT. With the advent of the Gothic novel, further Celtic obsessions and a rapidly changing political and religious landscape, the 1770s provided fertile ground for plays such as Caractacus to flourish. The concept of the sublime offers a new way to understand what Mason meant by 'on the model of the antient Greek tragedy', a new chapter in the influence of the Longinian sublime as a way of integrating political and religious sentiments in a new aesthetic framework.

Open Access This article is licensed under a Creative Commons Attribution 4.0 International License, which permits use, sharing, adaptation, distribution and reproduction in any medium or format, as long as you give appropriate credit to the original author(s) and the source, provide a link to the Creative Commons licence, and indicate if changes were made. The images or other third party material in this article are included in the article's Creative Commons licence, unless indicated otherwise in a credit line to the material. If material is not included in the article's Creative Commons licence and your intended use is not permitted by statutory regulation or exceeds the permitted use, you will need to obtain permission directly from the copyright holder. To view a copy of this licence, visit http://creativecommons.org/licen ses/by/4.0/.

\section{References}

Ambühl, A., 'Thebanos Imitate Rogos (BC.1,552) - Lucans Bellum Civile Und Die Tragödien Aus Dem Thebanischen Sagenkreis', in Lucan Im 21. Jahrhundert, ed. Christine Walde, München, 2005.

$\overline{\left.{ }^{90} \text { Hall and Macintosh (2005, p. } 214\right) .}$ 
Arthur, and Robert Southey, The Byrth, Lyf and Actes of Kyng Arthur, [Tr. by Sir T. Malory] with Intr. and Notes by R. Southey, London, 1817.

Bierl, Anton, Dionysos und die griechische Tragödie: politische und 'metatheatralische' Aspekte im Text, Tübingen, 1991.

Braudy, Leo, 'The Form of the Sentimental Novel'. NOVEL: A Forum on Fiction 7 (1), 1973, pp. 5-13.

Brewer, John, The Common People and Politics 1750s-1790s, English Satirical Print, 1600-1832, Cambridge, 1986.

Brown, Peter, and Suzana Ograjenšek, Ancient Drama in Music for the Modern Stage, Oxford, 2013.

Burke, Edmund, A Philosophical Enquiry into the Origin of Our Ideas of the Sublime and Beautiful, London, 1958.

Cheney, Patrick, Rita Copeland, Philip R. Hardie, David Hopkins, Charles Martindale, Norman Vance, and Jennifer Wallace, The Oxford History of Classical Reception in English Literature, History of Classical Reception in English Literature, Oxford, 2012.

Chignell, Andrew, and Matthew C. Halteman, 'Religion and the Sublime', in The Sublime: From Antiquity to the Present, ed. Timothy M. Costelloe, Cambridge, 2012, pp. 183-202.

Costelloe, Timothy M., The Sublime: From Antiquity to the Present, Cambridge, 2012.

Curran, John E., Roman Invasions : The British History, Protestant Anti-Romanism, and the Historical Imagination in England, 1530-1660, Newark, London, 2002.

Draper, John W., William Mason, a Study in Eighteenth-Century Culture, New York, 1924.

Easterling, P.E., 'The Death of Oedipus and What Happened Next', in Dionysalexandros. Essays on Aeschylus and His Fellow Tragedians in Honour of Alexander F. Garvie, ed. D. Cairns and Vayos Liapis, Swansea, 2006, pp. 133-50.

Ewans, Michael, Opera from the Greek: Studies in the Poetics of Appropriation, Aldershot, 2007.

Gaskell, Philip, The First Editions of William Mason, Monograph (Cambridge Bibliographical Society), Cambridge, 1951.

Hall, Edith, and Fiona Macintosh, Greek Tragedy and the British Theatre, 1660-1914, Oxford, 2005.

Hayley, William, An Essay on Epic Poetry, Dublin: Printed for S. Price, W. Sleater, J. Sheppard, W. and H. Whitestone, E. Lynch [and 13 others in Dublin], 1782.

Hunink, Vincent, M., Annaeus Lucanus, Bellum Civile Book III: A Commentary, Amsterdam, 1992.

Jebb, R.C., Sophocles : The Plays and Fragments. Part II, The Oedipus Coloneus, Cambridge, 1885.

Kalter, Barrett 'DIY Gothic: Thomas Gray and the Medieval Revival'. ELH 70 (4), 2003, pp. 989-1019.

Lauriola, Rosanna, 'Oedipus the King', in Brill's Companion to the Reception of Sophocles, ed. Rosanna Lauriola and Kyriakos N. Demetriou, Leiden, Netherlands, 2007, pp. 149-326.

Lees, J. C., 'The Religious Retinue of Leicester House: Chaplains of Frederick Louis, Prince of Wales, 1729-51', Journal for Eighteenth-Century Studies 40 (1), 2017, pp. 89-109.

Lewis, W.S. ed., The Yale Edition of Horace Walpole's Correspondence, New Haven, 1937.

Longinus, and William Smith, Dionysius Longinus on the Sublime: Translated from the Greek, with Notes and Observations, and Some Account of the Life, Writings, and Character of the Author. By William Smith, Dublin: Printed by S. Powell, for G. Risk, G. Ewing, and W. Smith, and E. Exshaw, 1740.

Macintosh, Fiona, 'Under the Blue Pencil: Greek Tragedy and the British Censor', Dialogos 2, 1995, pp. 54-70.

Mason, William, Antinomian Heresy Exploded: In an Appeal to the Christian World, London: Printed and Sold by M. Lewis, 1760.

Mason, William, The Absolute and Indispensible Duty of Christians [Electronic Resource], in This Critical Juncture, Considered and Enforced, in an Affectionate Address. By W. Mason. London: Printed and Sold by M. Lewis, 1775.

Mason, William, Animadversions on the Present Government of the York Lunatic Asylum [Electronic Resource], York: Printed by W. Blanchard: sold by J. Todd, and the rest of the booksellers, 1788.

Mason, William, Caractacus: A Dramatic Poem. Bell's British Theatre, London: Printed for, and under the direction of, George Cawthorn, 1796.

May, Gita 'Diderot and Burke: A Study in Aesthetic Affinity', PMLA 75 (5), 1960, pp. 527-39.

McDonald, Marianne, Sing Sorrow: Classics, History, and Heroines in Opera. Contributions to the Study of Music and Dance, No. 62. Westport, Conn, 2001.

Miller, John, Religion in the Popular Prints, 1600-1832. English Satirical Print, 1600-1832, Cambridge, England, 1986.

Piggott, Stuart, The Druids, Harmondsworth, 1974. 
Ryan, Cressida, 'Sophocles' Oedipus at Colonus in Eighteenth-Century England and France', PhD diss, University of Nottingham, 2010.

Ryan, Cressida, 'Burke's Classical Heritage: Playing Games with Longinus', in The Science of Sensibility: Reading Burke's Philosophical Enquiry, International Archives of the History of Ideas 206, Dordrecht, Heidelberg, London, New York, 2012, pp. 225-46.

Sambrook, James, James Thomson 1700-1748 : A Life, Oxford, 1991.

St John's Admissions Appendix. 1715-1767.

Publisher's Note Springer Nature remains neutral with regard to jurisdictional claims in published maps and institutional affiliations. 